\title{
Postnatal Changes in Trace Elements and in Oxidation-reduction Activity in Laboratory Bank Voles
}

\author{
Elżbieta MALZAHN
}

Malzahn E., 1983 : Postnatal changes in trace elements and in oxidationreduction activity in laboratory bank voles. Acta theriol, $28,3: 33-54$ [With 5 Tables \& 7 Figs.]

Examination was made of the concentrations of 10 trace elements ( $\mathrm{Fe}, \mathrm{Zn}, \mathrm{Co}, \mathrm{Se}, \mathrm{Sb}, \mathrm{Eu}, \mathrm{Cr}, \mathrm{Hg}, \mathrm{Sc}$ and $\mathrm{Ce}$ ) in the liver, kidneys and heart of the bank vole, Clethrionomys glareolus (Schreber, 1780) from spring and autumn generations, during the postnatal development ( $1-60$ days of life). The voles originated from the $8-12$ th inbred generation kept under laboratory conditions. Two types of elements were distinguished, differing as to their contents in the dry mass of vole organs from compared generations of the same age. Elements of type I (Fe, Co, $\mathrm{Se}, \mathrm{Sc})$ were found in greater amounts in organs of autumn generation than spring generation voles, and elements of type II ( $\mathrm{Sb}, \mathrm{Zn}, \mathrm{Eu}$ ) in voles of the spring than autumn generation. Maximum concentrations of elements occur in the organs of day-old or 10 day old voles, after which they decrease, during the period of development in the nest, parallel to changes in the oxidation-reduction activity of the organs. The activity of organs during postnatal development decreases from a high level to the low level characteristic of adult animals and reached by voles about the 30 th day of life, being maintained to at least the 240th day of life. Autumn generation voles have a higher level of activity after birth, but as from the 60th day of life the activity of spring generation vole organs is greater then in those of the autumn generation. The reverse differences were found between wild voles of seasonal generations in comparison with laboratory voles.

[Mammals Res. Inst., Polish Acad. Sci., 17-230 Białowieża, Poland]

\section{INTRODUCTION}

The role of different trace elements as essential components of numerous metabolically active compounds in the organism, playing an active part in control of indirect metabolism, is still a debatable question (Underwood, 1971; Davies, 1977; Kabata-Pendias \& Pendias, 1979). Data are still being amassed on trace element content in organs and organism fluids of animals, serving as a criterion for defining the as yet unknown requirements of animals for different elements.

Concentrations of elements in organs of the bank vole obtained from the Białowieża Primeval Forest, one of the least polluted natural habitats in Poland (Grodzińska, 1980) may be regarded as a zero index for this species of small mammal. The vole is an interesting object for study, on account of the wide range of its occurrence and the 
relatively well known biology of this species. The analysis made previously of variability of 10 trace elements in organs of wild bank voles, i.e. the first generation obtained from parents caught in the Białowieża National Park, made it possible to obtain data on the course taken by metabolic changes in these animals during the postnatal development of different seasonal generations (Malzahn, 1981). The concentration of trace elements in vole organs has been related to control of the level of their oxidation-reduction activity, which varies with the animals age. It was found that seasonal generations of the bank vole, fulfilling an important role in maintaining the biological continuity of the species (Petrusewicz et al., 1969/70) differ from each other as to level and variations of both the metabolic indices examined during postnatal development. In laboratory voles, however, no differences were found in certain of the physiological indices between individuals born in different seasons (Fedyk, 1974a).

In order to analyze physiological differences in the rate of individual growth and development within the whole species C. glareolus, it was decided to examine variations in the concentration of trace elements in organs and their oxidation-reduction activity in laboratory voles of different seasonal generations and to compare these results with those obtained earlier on for wild voles.

\section{MATERIAL AND METHODS}

The voles originated from the 8-12th inbred generation kept in the Mammals Research Institute at Białowieża (Buchalczyk, 1970). The young were taken from their mothers when 20 days old, and each individual was kept separately. Their food consisted of oats, beets and carrots, with water ad libitum. Voles born during the period from March to the end of May (spring generation) and from October to December (autumn generation) were used for the experiments. Analysis was made of voles aged $1,10,20,30,60$ and 240 days old. A total of 394 animals were used in the experiments (190 from the spring generation and 204 from the autumn generation). The animals were anaesthetized with ether. The dissected organs: liver, kidneys and heart - were washed in distilled water, dried on filter paper and weighed. Further preparation of organs for analysis depended on the study methods.

The instrumental neutron activation analysis (INAA) was used to examine concentration of trace elements in the organs (Jakutowicz, 1973). Preparation of organ samples consisted in drying each organ at a temperature of $105^{\circ} \mathrm{C}$ to dry mass, then triturating it in an agate mortar. In view of the large number of samples and very small weight of certain of them, particularly from day-old voles, individual identifications were not made, but the dry mass of vole organs of identical age were combined: in the first, tenth, twentieth, thirtieth and sixtieth day of the animals' life, i.e. during the period in which the percentage of mineral substances increases in the structure of the fat-free body mass of voles 
(Fedyk, 1974a). Samples taken from triturated dry mass of different organs, obtaining an average by mixing combined dry mass of different organs from about 10 to about $250 \mathrm{mg}$ in weight, simultaneously with prepared quantitative standard samples, were irradiated in an EWA nuclear reactor (Swierk). The gamma radiation spectrum was analyzed by means of a semi-conductor detector $(\mathrm{Ge} / \mathrm{Li})$ after $20-60$ days from time of irradiation. Nuclear properties of identified nuclides have been described in the paper by Malzahn (1981). Results of identifications have been given in the form of concentration i.e. $\mu \mathrm{g} / 1 \mathrm{~g}$ dry mass (ppm) and in the form of contents $(\mu \mathrm{g})$ in total mean dry mass of one vole organ in different age groups.

The oxidation-reduction activity of vole organs was determined by the chemiluminescence method (Malzahn, 1978). Weak chemiluminescence (CHL) reaction of pyrogallol oxidation by hydrogen peroxide was used as a basis. $0.1 \mathrm{ml}$ of tissue homogenate obtained by homogenizing whole organs with the addition of KrebsRinger solution ( $\mathrm{pH} 7.4$ ), in parts of $0.5 \mathrm{ml}$ solution to each $100 \mathrm{~g}$ of fresh tissue mass, was added to such a model reaction. The sum total of the number of impulses obtained from calculations of the electron counter from the time of adding the homogenate to the model reaction up to the time reaction ended, was treated as the activity of the organ examined. Determinations were made of the activity for voles in the same age groups in which trace element concentration had been examined, and in those 240 days old, in order to determine whether organ activity level changes as the animals get older.

The results obtained were statistically analyzed, using the Student $t$ test and variance analysis with the new multiple range test. Calculation was made of the coefficients of correlation and regression equation between oxidation-reduction activity and weight of vole organs during postnatal development.

\section{RESULTS}

Voles of the autumn generation were heavier than those of the spring generation only on the first and tenth day of life (Table 1). There were no statistically significant differences in the weight of voles from these generations in subsequent age groups. Absolute mass of organs increases in voles of the two generations, but in the younger age groups kidney and heart masses were greater in autumn than in spring generation voles, whereas in the older age groups (60 and 240 days) they were greater in voles of the spring than of the autumn generation. Dry mass weight and contents by percentage of dry mass in the organs were similar in the two generations.

\subsection{Occurrence of Trace Elements in Organs}

Of the 10 trace elements identified, six (Fe, $\mathrm{Zn}, \mathrm{Co}, \mathrm{Se}, \mathrm{Sb}$ and $\mathrm{Eu}$ ) occurred in each sample, while it proved possible to identify four $(\mathrm{Cr}$, $\mathrm{Hg}$, Sc and $\mathrm{Ce}$ ) and label four quantitatively in only some of the samples (Table 2). Concentrations of several elements in some of the samples were on the borderline of the method's sensitivity, and they were therefore labelled only semiquantitatively, giving the threshold value. 
Table 1

Body weight ( $\mathrm{g}$ ) and absolute weights (mg) a) and dry mass ( $\mathrm{mg}$ ) b) of the organs of laboratory voles of different generations during postnatal development. $\mathrm{NS}=$ differences between generations not significant, $\mathrm{S}=$ differences between generations significant with $\mathrm{P}<.01$ (Student $t$ test).

\begin{tabular}{|c|c|c|c|c|c|c|c|c|}
\hline \multirow{2}{*}{$\begin{array}{l}\text { Age, } \\
\text { days }\end{array}$} & & \multicolumn{3}{|c|}{ Spring generation } & \multicolumn{3}{|c|}{ Autumn generation } & \multirow[t]{2}{*}{ Diff. } \\
\hline & & $\mathrm{N}$ & $\overline{\mathrm{x}} \pm$ S.D. & (CV) & $\mathrm{N}$ & $\overline{\mathrm{x}} \pm$ S.D & (CV) & \\
\hline \multicolumn{9}{|c|}{ Body weight } \\
\hline 1 & & 50 & $1.9 \pm 0.4$ & (20.1) & 46 & $2.1 \pm 0.4$ & (17.9) & s \\
\hline 10 & & 34 & $4.6 \pm 0.7$ & $(16.0)$ & 40 & $5.2 \pm 0.9$ & $(17.2)$ & $\mathbf{S}$ \\
\hline 20 & & 29 & $7.8 \pm 1.3$ & (17.0) & 41 & $7.8 \pm 1.7$ & (22.0) & NS \\
\hline 30 & & 34 & $11.6 \pm 2.3$ & (19.6) & 29 & $12.8 \pm 2.2$ & (17.1) & NS \\
\hline 60 & & 33 & $15.8 \pm 1.6$ & $(10.0)$ & 38 & $14.7 \pm 2.4$ & (16.4) & NS \\
\hline 240 & & 10 & $20.0 \pm 4.2$ & $(20.8)$ & 10 & $19.1 \pm 2.1$ & (11.2) & NS \\
\hline \multicolumn{9}{|c|}{ Liver } \\
\hline 1 & $\begin{array}{l}\text { a) } \\
\text { b) }\end{array}$ & $\begin{array}{l}36 \\
26\end{array}$ & $\begin{array}{c}134 \pm 27 \\
19.9 \pm 5.2\end{array}$ & $\begin{array}{l}(20.7) \\
(26.1)\end{array}$ & $\begin{array}{l}40 \\
30\end{array}$ & $\begin{array}{c}149 \pm 31 \\
20.8 \pm 4.7\end{array}$ & $\begin{array}{l}(20.5) \\
(22.8)\end{array}$ & $\begin{array}{l}\text { NS } \\
\text { NS }\end{array}$ \\
\hline 10 & $\begin{array}{l}\text { a) } \\
\text { b) }\end{array}$ & $\begin{array}{l}34 \\
24\end{array}$ & $\begin{array}{c}219 \pm 44 \\
39.6 \pm 7.7\end{array}$ & $\begin{array}{l}(20.3) \\
(19.5)\end{array}$ & $\begin{array}{l}40 \\
30\end{array}$ & $\begin{array}{c}249 \pm 62 \\
42.5 \pm 12.4\end{array}$ & $\begin{array}{l}(25.1) \\
(29.3)\end{array}$ & $\begin{array}{l}\text { NS } \\
\text { NS }\end{array}$ \\
\hline 20 & $\begin{array}{l}\text { a) } \\
\text { b) }\end{array}$ & $\begin{array}{l}29 \\
19\end{array}$ & $\begin{array}{r}551 \pm 111 \\
117.7 \pm 27.8\end{array}$ & $\begin{array}{l}(20.2) \\
(23.6)\end{array}$ & $\begin{array}{l}40 \\
30\end{array}$ & $\begin{array}{r}518 \pm 140 \\
114.0 \pm 35.0\end{array}$ & $\begin{array}{l}(27.1) \\
(30.7)\end{array}$ & $\begin{array}{l}\text { NS } \\
\text { NS }\end{array}$ \\
\hline 30 & $\begin{array}{l}\text { a) } \\
\text { b) }\end{array}$ & $\begin{array}{l}33 \\
23\end{array}$ & $\begin{array}{c}850 \pm 161 \\
176.0 \pm 36.9\end{array}$ & $\begin{array}{l}(18.9) \\
(21.0)\end{array}$ & $\begin{array}{l}29 \\
19\end{array}$ & $\begin{array}{c}830 \pm 208 \\
180.9 \pm 52.0\end{array}$ & $\begin{array}{l}(25.0) \\
(29.2)\end{array}$ & $\begin{array}{l}\text { NS } \\
\text { NS }\end{array}$ \\
\hline 60 & $\begin{array}{l}\text { a) } \\
\text { b) }\end{array}$ & $\begin{array}{l}33 \\
23\end{array}$ & $\begin{array}{c}1087 \pm 195 \\
240.8 \pm 47.6\end{array}$ & $\begin{array}{l}(17.9) \\
(19.8)\end{array}$ & $\begin{array}{l}38 \\
28\end{array}$ & $\begin{array}{r}964 \pm 224 \\
228.7 \pm 46.9\end{array}$ & $\begin{array}{l}(23.2) \\
(20.5)\end{array}$ & $\begin{array}{l}\text { NS } \\
\text { NS }\end{array}$ \\
\hline 240 & a) & 10 & $1066 \pm 191$ & $(17.9)$ & 10 & $1094 \pm 205$ & (18.7) & NS \\
\hline \multicolumn{9}{|c|}{ Kidneys } \\
\hline 1 & $\begin{array}{l}\text { a) } \\
\text { b) }\end{array}$ & $\begin{array}{l}36 \\
26\end{array}$ & $\begin{array}{c}35 \pm 12 \\
3.2 \pm 1.3\end{array}$ & $\begin{array}{l}(35.4) \\
(36.7)\end{array}$ & $\begin{array}{l}40 \\
30\end{array}$ & $\begin{array}{c}38 \pm 10 \\
3.7 \pm 1.3\end{array}$ & $\begin{array}{l}(26.2) \\
(35.2)\end{array}$ & $\begin{array}{l}\text { NS } \\
\text { NS }\end{array}$ \\
\hline 10 & $\begin{array}{l}\text { a) } \\
\text { b) }\end{array}$ & $\begin{array}{l}34 \\
24\end{array}$ & $\begin{array}{r}80 \pm 15 \\
10.7 \pm 1.6\end{array}$ & $\begin{array}{l}(18.6) \\
(15.1)\end{array}$ & $\begin{array}{l}40 \\
30\end{array}$ & $\begin{array}{r}106 \pm 28 \\
11.7 \pm 3.3\end{array}$ & $\begin{array}{l}(26.9) \\
(27.8)\end{array}$ & $\begin{array}{l}\text { S } \\
\text { NS }\end{array}$ \\
\hline 20 & $\begin{array}{l}\text { a) } \\
\text { b) }\end{array}$ & $\begin{array}{l}29 \\
19\end{array}$ & $\begin{array}{r}169 \pm 33 \\
27.7 \pm 6.9\end{array}$ & $\begin{array}{l}(19.3) \\
(25.1)\end{array}$ & $\begin{array}{l}40 \\
30\end{array}$ & $\begin{array}{c}161 \pm 37 \\
26.7 \pm 7.2\end{array}$ & $\begin{array}{l}(23.3) \\
(27.9)\end{array}$ & $\begin{array}{l}\text { NS } \\
\text { NS }\end{array}$ \\
\hline 30 & $\begin{array}{l}\text { a) } \\
\text { b) }\end{array}$ & $\begin{array}{l}33 \\
23\end{array}$ & $\begin{array}{c}211 \pm 41 \\
36.0 \pm 7.7\end{array}$ & $\begin{array}{l}(19.5) \\
(21.3)\end{array}$ & $\begin{array}{l}29 \\
19\end{array}$ & $\begin{array}{r}184 \pm 35 \\
35.6 \pm 5.2\end{array}$ & $\begin{array}{l}(18.8) \\
(14.6)\end{array}$ & $\begin{array}{r}\text { S } \\
\text { NS }\end{array}$ \\
\hline 60 & $\begin{array}{l}\text { a) } \\
\text { b) }\end{array}$ & $\begin{array}{l}33 \\
23\end{array}$ & $\begin{array}{c}234 \pm 31 \\
47.0 \pm 5.0\end{array}$ & $\begin{array}{l}(13.2) \\
(10.7)\end{array}$ & $\begin{array}{l}38 \\
28\end{array}$ & $\begin{array}{r}194 \pm 47 \\
41.5 \pm 9.6\end{array}$ & $\begin{array}{l}(24.2) \\
(23.1)\end{array}$ & $\begin{array}{r}\mathrm{S} \\
\mathrm{NS}\end{array}$ \\
\hline 240 & a) & 10 & $259 \pm 37$ & (14.1) & 10 & $213 \pm 32$ & (15.3) & NS \\
\hline \multicolumn{9}{|c|}{ Heart } \\
\hline 1 & $\begin{array}{l}\text { a) } \\
\text { b) }\end{array}$ & $\begin{array}{l}49 \\
25\end{array}$ & $\begin{array}{c}14 \pm 4 \\
1.3 \pm 0.6\end{array}$ & $\begin{array}{l}(30.3) \\
(50.3)\end{array}$ & $\begin{array}{l}46 \\
30\end{array}$ & $\begin{array}{l}17 \pm 5 \\
1.6 \pm 0.9\end{array}$ & $\begin{array}{l}(30.9) \\
(55.9)\end{array}$ & $\stackrel{S}{\mathrm{~S}}$ \\
\hline 10 & $\begin{array}{l}\text { a) } \\
\text { b) }\end{array}$ & $\begin{array}{l}34 \\
24\end{array}$ & $\begin{array}{c}37 \pm 8 \\
4.9 \pm 2.7\end{array}$ & $\begin{array}{l}(21.2) \\
(55.0)\end{array}$ & $\begin{array}{l}40 \\
30\end{array}$ & $\begin{array}{r}42 \pm 10 \\
4.8 \pm 1.9\end{array}$ & $\begin{array}{l}(22.9) \\
(40.1)\end{array}$ & $\stackrel{S}{N S}$ \\
\hline 20 & $\begin{array}{l}\text { a) } \\
\text { b) }\end{array}$ & $\begin{array}{l}29 \\
19\end{array}$ & $\begin{array}{r}75 \pm 17 \\
11.3 \pm 2.4\end{array}$ & $\begin{array}{l}(22.2) \\
(21.2)\end{array}$ & $\begin{array}{l}40 \\
30\end{array}$ & $\begin{array}{c}66 \pm 15 \\
9.0 \pm 3.6\end{array}$ & $\begin{array}{l}(23.4) \\
(40.2)\end{array}$ & $\begin{array}{l}\text { NS } \\
\text { NS }\end{array}$ \\
\hline 30 & $\begin{array}{l}\text { a) } \\
\text { b) }\end{array}$ & $\begin{array}{l}33 \\
23\end{array}$ & $\begin{array}{c}98 \pm 19 \\
13.6 \pm 3.3\end{array}$ & $\begin{array}{l}(19.6) \\
(24.0)\end{array}$ & $\begin{array}{l}29 \\
19\end{array}$ & $\begin{array}{c}93 \pm 20 \\
16.5 \pm 2.8\end{array}$ & $\begin{array}{l}(21.2) \\
(16.7)\end{array}$ & $\begin{array}{r}\mathrm{NS} \\
\mathrm{S}\end{array}$ \\
\hline 60 & $\begin{array}{l}\text { a) } \\
\text { b) }\end{array}$ & $\begin{array}{l}32 \\
22\end{array}$ & $\begin{array}{c}114 \pm 18 \\
19.1 \pm 2.6\end{array}$ & $\begin{array}{l}(15.4) \\
(13.4)\end{array}$ & $\begin{array}{l}38 \\
28\end{array}$ & $\begin{array}{c}100 \pm 17 \\
15.9 \pm 3.8\end{array}$ & $\begin{array}{l}(17.1) \\
(24.0)\end{array}$ & $\stackrel{S}{S}$ \\
\hline$\underline{240}$ & a) & 10 & $114 \pm 14$ & $(12.3)$ & 10 & $108 \pm 13$ & $(11.8)$ & NS \\
\hline
\end{tabular}




\subsubsection{Concentration of Trace Elements}

Concentrations of elements constantly occurring in organs changes to a different degree during the voles' postnatal development. Thus $\mathrm{Zn}$ and Co (differences 4-19 times) are elements with relatively slight variability, medium variability - Fe, Se and Sb (differences 250-430 times) and considerable variability - Eu (differences over 3200-times).

Concentrations of elements in different organs did not alter regularly with the animals' age. From birth up to the 20th day of life, that is, until separated from the mother, concentrations of the majority of elements decreased in vole organs, only concentrations of $\mathrm{Fe}$ increasing in all organs. Fe was also the only element whose concentration in the majority of samples increased up to the 60th day of the voles' life in both generations. Voles of extreme seasonal generations differed distinctly in respect of $\mathrm{Fe}$ concentration in organs. Newborn voles of the autumn generation have 7 times greater $\mathrm{Fe}$ concentration in the liver, 12 times greater in kidneys and 5 times greater in the heart than was the case with spring generation voles. This difference was maintained in the liver and heart, but in kidneys decreased up to the 60th day of the animals life. Among the organs examined maximum $\mathrm{Fe}$ concentration occurred in the liver of both generations of voles.

$\mathrm{Zn}$ concentrations were most similar to each other in different organs in comparison with other elements. Greatest variations in $\mathrm{Zn}$ concentration were found in vole hearts. Maximum $\mathrm{Zn}$ concentration occurred in all organs in newborn voles. $\mathrm{Zn}$ concentrations also differ in the organs of the generations of voles compared. Day-old voles of the spring generation contained about twice higher concentrations of $\mathrm{Zn}$ in the liver and kidneys and about 3 times greater in the heart in comparison with autumn generation voles. These differences persisted through the whole period of development studied and 60-day old voles of the spring generation had about 1.5 times higher $\mathrm{Zn}$ concentration in all the organs examined than voles of the autumn generation. $\mathrm{Zn}$ concentration in the majority of organs decreased with age in relation to concentrations in newborn voles, but were subject to slight variations in animals over 30 days old.

It was possible to label Co concentrations semi-quantitatively only in all organs of spring generation vole organs. The course of variations in Co concentration during postnatal development was similar in the liver and heart, but differed from other organs - in the kidneys. A particularly great difference between voles of the two generations in respect of Co concentration was found in livers of voles, particularly newborn ones (about 20 times).

Se concentrations in autumn generation voles were higher than in 
those of the spring generation in all organs as from the 30th day of life. In day-old voles, however, there were higher Se concentrations in all organs of spring generation voles than in those from autumn. The very high Se concentrations in the newborn voles of both generations were remarkable. As in the case of other elements, the greatest differences between generations occurred in the Se concentrations in vole kidneys.

$\mathrm{Sb}$ concentrations in vole organs varied irregularly during their development. Abrupt increases and decreases in Sb concentration in organs were recorded. Greater $\mathrm{Sb}$ concentration occurred in organs of spring generation voles than autumn. Difference between $\mathrm{Sb}$ concentrations in liver and heart of voles of the generations compared increased with the animals' age, but decreased in kidneys, and on the 60th day of life there was no differences between the spring and autumn generation.

$\mathrm{Eu}$ concentrations differed most from each other in the organs of voles of different age. In autumn generation voles $\mathrm{Eu}$ concentration could be labelled only semi-quantitatively. Whereas in spring generation voles very high Eu concentrations were recorded in all the organs of newborn voles, with marked decrease in concentrations in the organs between the first and 10th day of life. Throughout the whole study period of postnatal development Eu concentration in all organs of spring generation voles decreased with the animals' age.

Trace elements found sporadically in samples usually occurred in the organs of voles of different generations from the lst to the 20th day of the animals' life. No $\mathrm{Cr}$ was found in kidneys or $\mathrm{Hg}$ in the hearts of voles of either generation, and $\mathrm{Cr}$ in any of the organs of spring generation voles, and $\mathrm{Ce}$ in the liver and heart of spring generation voles. $\mathrm{Cr}$ was identified in the liver of autumn generation voles from the 1st to 20th day of life, in concentrations decreasing with the animals' age. $\mathrm{Hg}$ occurred in the liver and kidneys of newborn voles only. Sc was found in the kidneys and heart of autumn generation voles only. Ce occurred in the liver of autumn generation voles in all age groups.

Maximum concentrations of the majority of trace elements were found in organs of voles of both generations on the 1st or 10th day of the animals life, after which there was a distinct decrease in concentration up to the 20th day of life. Variations in concentration of elements in different organs were greatest in voles of both generations from the 10 th to 30 th day of life. During the final part of the development period examined, i.e. between the 30 th and 60 th day of the voles' life, concentrations of the majority of elements in kidneys and heart were subject to small fluctuations, but increased in the liver of spring gener- 
Table 2

Concentrations of trace elements (ppm) in organs of laboratory voles of different generations during postantal development.

$\mathrm{S}$ - spring generation; A-autumn generation.

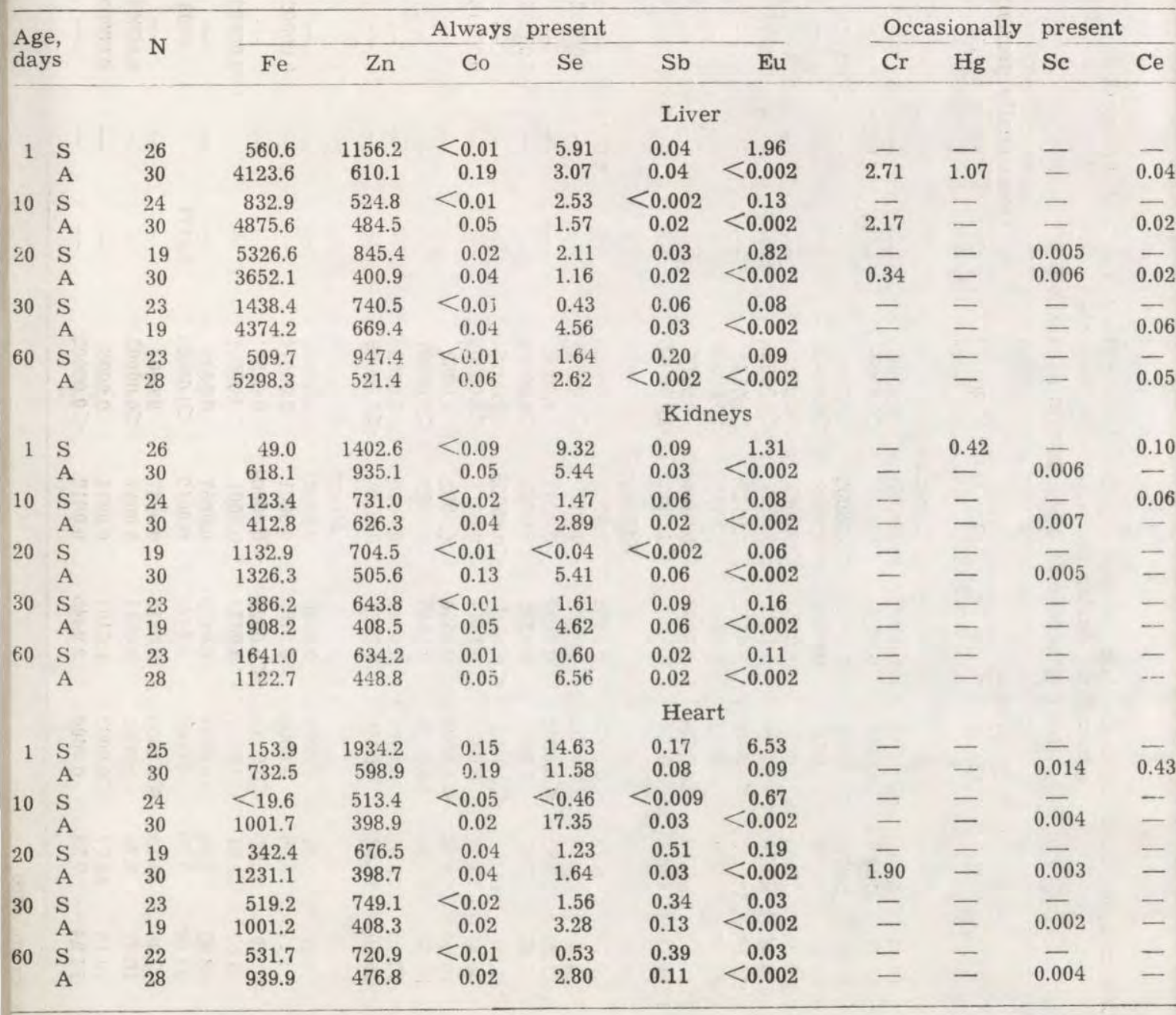

E. Malzahn, wklejka str, $38 / 39$, 


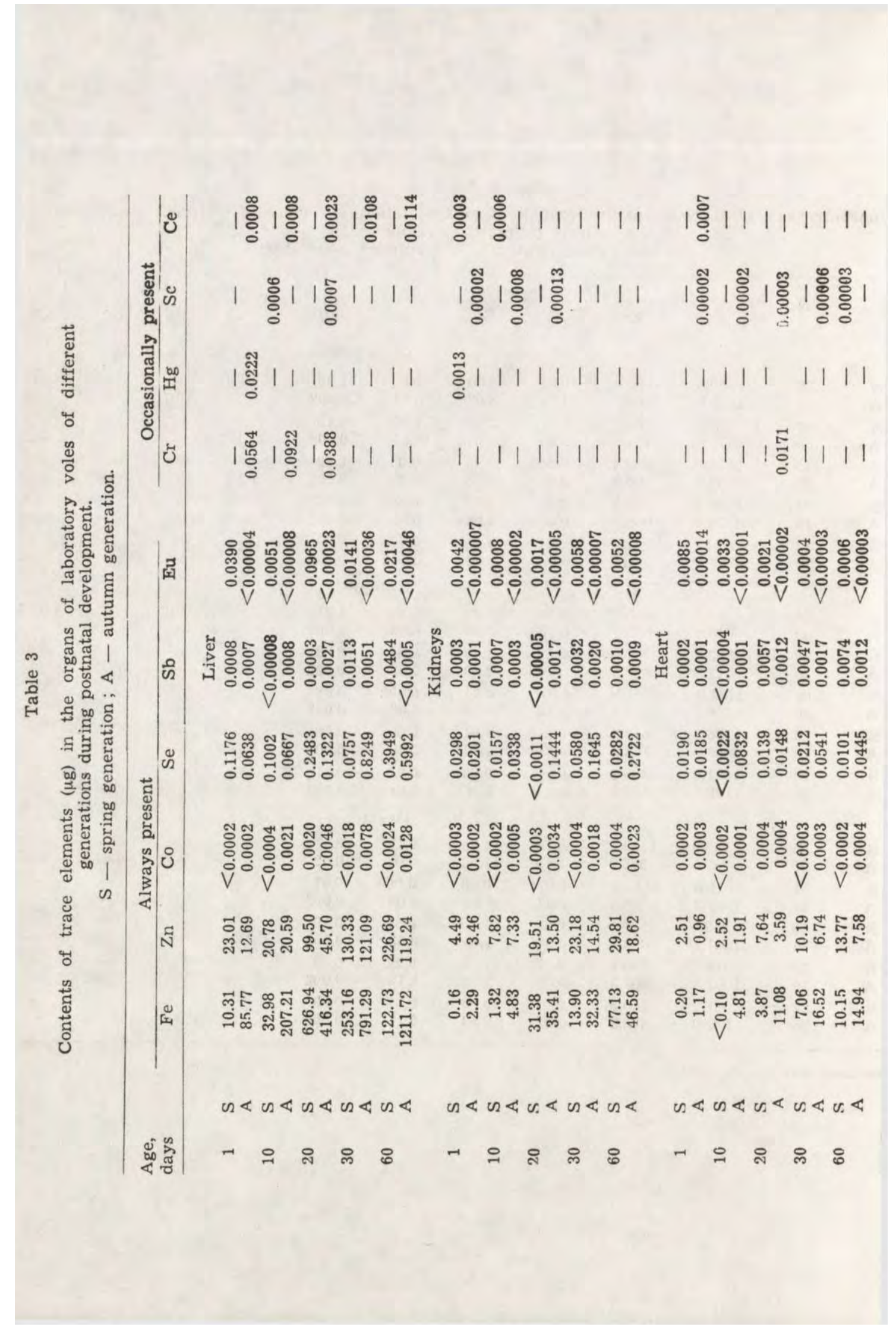


ation voles, while decreasing in autumn generation voles. Average concentrations of elements for the whole development period in different organs differed in voles of extreme seasonal generations (Fig. 1). Average concentrations of $\mathrm{Se}, \mathrm{Sb}$ and $\mathrm{Eu}$ were greatest in voles of both generations in the heart, and medium concentrations of $\mathrm{Fe}$ in the liver. Medium concentrations of $\mathrm{Fe}$ and $\mathrm{Se}$ in all organs were $1.4-3$ times greater, and Co even 7 times greater, in autumn generation voles than

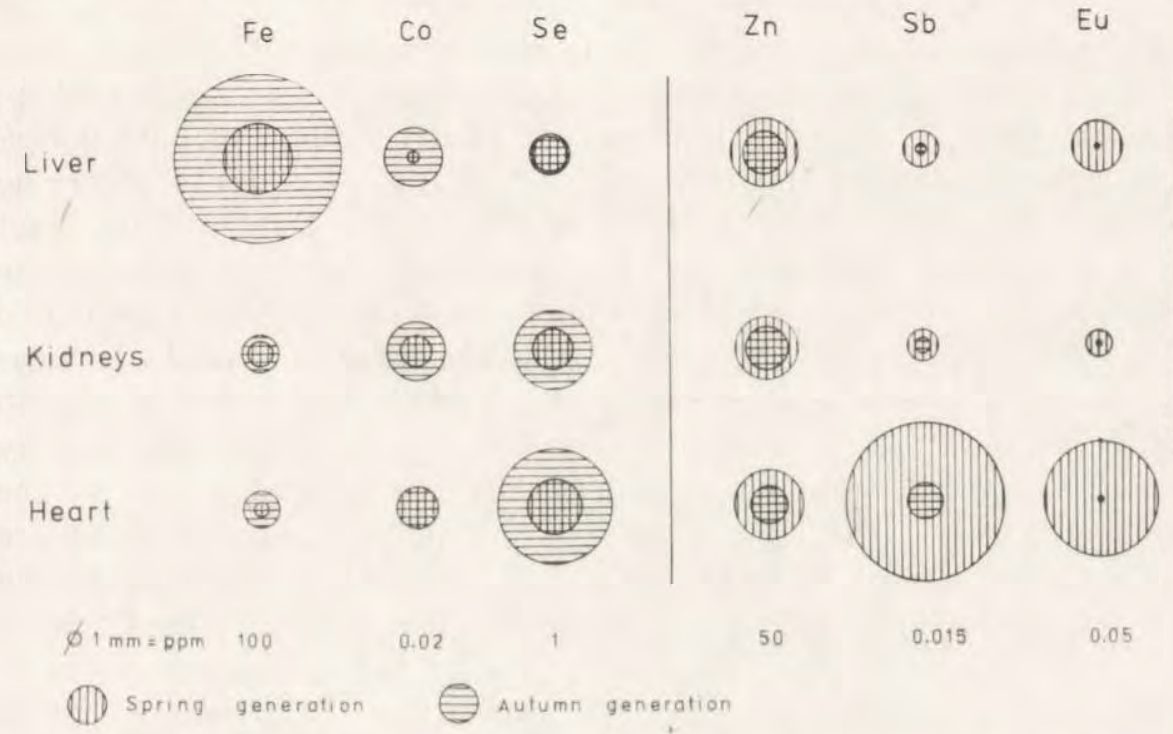

Fig. 1. Mean concentrations of trace elements in the organs of laboratory voles of different generations, during postnatal development.

in the spring generation, while medium concentrations of $\mathrm{Zn}$ and $\mathrm{Sb}$ in all organs were 1.5-4 times greater, and Eu even 74-308 times greater in spring than in autumn generation voles.

\subsubsection{Contents of Trace Elements}

Contents of the majority of elements in the total dry mass of vole organs usually increased with increasing weight of organ dry mass during the animals' postnatal development (Table 3).

Contents of elements in the liver of voles from the last age group on the 60th day of life - in relation to their contents in the liver of newborn voles of the spring generation, were in the case of $\mathrm{Fe}-12$ times greater, $\mathrm{Zn}-10$ times, $\mathrm{Se}-3$ times and $\mathrm{Sb}-59$ times, and in autumn generation voles: $\mathrm{Fe}-14$ times, $\mathrm{Zn}-10$ times, $\mathrm{Co}-3$ times, Se -9 times and $\mathrm{Ce}-14$ times. There was a higher content of $\mathrm{Eu}$ in the liver of newborn than 60-day old animals for spring generation voles, and of $\mathrm{Sb}$ for the autumn generation. Elements found in 
greater amounts in the liver of voles of the autumn than spring generation, in each or the majority of age groups, were $\mathrm{Fe}, \mathrm{Co}, \mathrm{Se}$, and sporadically found elements. There was a greater amount of $\mathrm{Eu}, \mathrm{Zn}$, and $\mathrm{Sb}$ in the liver of spring generation voles than in those of the autumn generation. Particularly great differences occurred in Eu contents in the liver of voles of the two generations compared - even in newborn voles there was over 975 times more $\mathrm{Eu}$ in the spring generation than in the autumn generation.

During postnatal development regular increase in $\mathrm{Zn}$ contents was found in the kidneys of voles of both generations, and of Se in autumn generation voles. Increase in iron content in the kidneys of both generations was arrested on the thirtieth day of life. In kidneys of spring generation voles $\mathrm{Se}, \mathrm{Sb}$ and $\mathrm{Eu}$ contents decreased during the first period of life, to rise again until a maximum was reached on the thirtieth day of life, after which they again decreased or were maintained on the same level up to the 60th day of the animals' life. In kidneys of the autumn generation voles, however, increase was found in $\mathrm{Co}, \mathrm{Sb}$ and Sc contents during the first period of their lives, followed by a decrease in their contents between the 20th and 60th day of the animals' life. As in the case of the liver, autumn generation voles are characterized by more regular increase in contents of elements during postnatal development than in those of the spring generation. Contents of elements in organs from voles in the final age group, examined in relation to their contents in kidneys of newborn voles of the spring generation, were 482 times greater in the case of $\mathrm{Fe}, 7$ times for $\mathrm{Zn}$ and 4 times for $\mathrm{Sb}$. In autumn generation voles, on the other hand, contents were 20 times greater for Fe, 5 times greater for $\mathrm{Zn}, 11$ times greater for $\mathrm{Co}, 13$ times for $\mathrm{Se}$ and 8 times for $\mathrm{Sb}$. Contents of $\mathrm{Eu}$ and Se were similar in newborn and 60-day old voles of the spring generation. $\mathrm{Fe}, \mathrm{Co}, \mathrm{Se}$ and $\mathrm{Sc}$ were elements with higher contents in the kidneys of autumn generation than spring generation voles in every, or at least the majority of age groups. There was higher concentration of $\mathrm{Zn}, \mathrm{Sb}, \mathrm{Eu}$ and $\mathrm{Ce}$ in the kidneys of spring generation voles. As early as the first day of life $\mathrm{Eu}$ contents were 600 times higher in the kidneys of spring generation than autumn generation voles and were maintained up to a level of 40 times higher contents on the 60th day of the animals' life. No elements from the group occurring sporadically in samples were identified in kidneys of 30 - and 60-day old voles.

Regular increase in $\mathrm{Zn}$ contents only was found in the heart of voles from both generations during their postnatal development. Increase in iron contents was arrested on the 10th day of life of spring generation voles and on the 30 th day of life of autumn generation voles. The 
remaining elements were characterized by irregular increase in contents in the heart of voles during their development : contents often decreased during the first period of life and reached a maximum on the 30th day. Contents of elements in hearts of voles in the final age group, in relation to contents in those of newborn voles of the spring generation, were 50 times greater for $\mathrm{Fe}, 5$ times for $\mathrm{Zn}, 32$ times for $\mathrm{Sb}$, and in autumn generation voles - 13 times for Fe, 8 times for $\mathrm{Zn}$, twice for Se, 9 times for $\mathrm{Sb}$ and 3 times for Sc. Se and Eu contents were greater in the heart of newborn than 60 day old voles of the spring generation. Elements with contents higher in the heart of autumn generation than spring generation voles in every, or the majority of age groups were $\mathrm{Fe}, \mathrm{Co}$, $\mathrm{Se}$ and $\mathrm{Sc}$, while high contents of $\mathrm{Zn}, \mathrm{Sb}$ and $\mathrm{Eu}$ were found in the heart of spring generation voles.

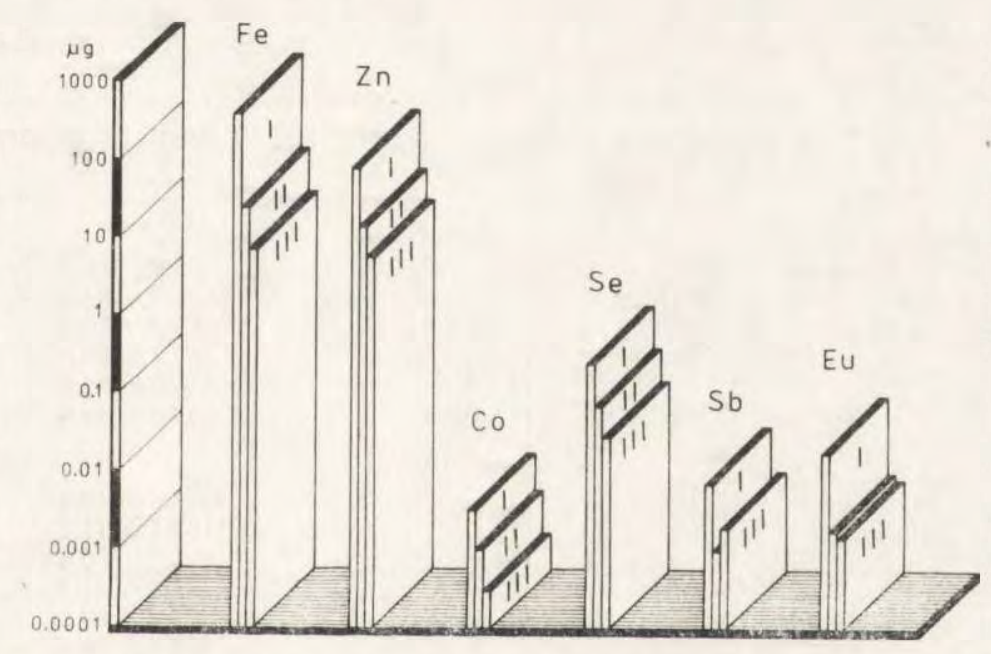

Fig. 2. Mean contents of trace elements in the organs of laboratory voles of two generations during postnatal development. I - liver; II - kidneys; III - heart.

When comparing differences between contents of elements in the organs of voles from the two generations it can be seen that there was decidedly greater amounts of $\mathrm{Fe}, \mathrm{Co}$ and $\mathrm{Sc}$, and smaller amounts of $\mathrm{Zn}$, Se, $\mathrm{Sb}$ and $\mathrm{Eu}$ in newborn voles of the autumn than of the spring generation. The greatest differences in element contents occurred in the liver of day-old voles of the generations compared. Sexually mature voles were characterized by markedly higher contents of $\mathrm{Fe}, \mathrm{Co}$ and $\mathrm{Se}$, and far lower contents of $\mathrm{Zn}, \mathrm{Sb}$ and $\mathrm{Eu}$ in all organs of voles of the autumn than the spring generation.

Average contents of trace elements occurring constantly in organs, calculated for all voles without division into age groups and generations, 
were highest in the liver and lowest in the heart, with the exception of $\mathrm{Sb}$, the minimum average contents of which were found in kidneys (Fig. 2).

\subsection{Oxidation-reduction Activity of Organs}

The oxidation-reduction activity of vole organs decreased to different degrees with the animals' increasing age (Table 4). The level and degree of decrease in activity was characteristic of the organ and depended on the season at which the voles were born.

Each organ had three activity levels during the postnatal development of the voles (Fig. 3).

Table 4

Oxidation-reduction activity (thousands of impulses) of the organs of laboratory voles of different generations during postnatal development. $\mathrm{N}=10$ in each age group.

\begin{tabular}{|c|c|c|c|c|c|}
\hline \multirow{3}{*}{$\begin{array}{l}\text { Age, } \\
\text { days }\end{array}$} & \multicolumn{3}{|c|}{ Spring generation } & \multicolumn{2}{|c|}{ Autumn generation } \\
\hline & & $\overline{\mathrm{x}} \pm$ S.D. & (CV) & $\overline{\mathrm{x}} \pm$ S.D. & $(\mathrm{CV})$ \\
\hline & \multicolumn{5}{|c|}{ Liver } \\
\hline 1 & & $3147.9 \pm 215.3$ & $(6.8)$ & $3255.9 \pm 211.3$ & $(6.5)$ \\
\hline 10 & & $2596.6 \pm 183.9$ & (7.1) & $2601.7 \pm 134.2$ & $(5.2)$ \\
\hline 20 & & $573.5 \pm 36.1$ & (6.3) & $601.4 \pm 29.8$ & $(5.0)$ \\
\hline 30 & & $527.3 \pm \quad 34.6$ & (6.6) & $567.1 \pm 32.0$ & (5.6) \\
\hline 60 & & $301.6 \pm 25.8$ & (8.5) & $239.9 \pm 22.5$ & (8.8) \\
\hline \multirow[t]{2}{*}{240} & & $349.6 \pm \quad 43.8$ & (12.5) & $239.3 \pm 32.5$ & (13.6) \\
\hline & \multicolumn{5}{|c|}{ Kidneys } \\
\hline 1 & & $4250.5 \pm 419.8$ & (9.9) & $4894.4 \pm 345.2$ & $(7.0)$ \\
\hline 10 & & $1523.9 \pm 246.8$ & (16.2) & $1783.1 \pm 171.2$ & (9.6) \\
\hline 20 & & $382.7 \pm \quad 45.5$ & (11.9) & $476.9 \pm 30.6$ & (6.4) \\
\hline 30 & & $344.0 \pm 23.1$ & $(6.7)$ & $431.1 \pm 41.3$ & $(9.6)$ \\
\hline 60 & & $339.6 \pm 24.7$ & $(7.3)$ & $292.3 \pm 30.3$ & (10.3) \\
\hline \multirow[t]{2}{*}{240} & & $369.6 \pm 21.3$ & $(5.7)$ & $298.0 \pm 28.4$ & (95) \\
\hline & \multicolumn{5}{|c|}{ Heart } \\
\hline 1 & & $10739.3 \pm 1127.6$ & $(10.6)$ & $12892.4 \pm 427.6$ & (3.3) \\
\hline 10 & & $12924.6 \pm 499.4$ & (3.9) & $14017.9 \pm 455.0$ & (3.2) \\
\hline 20 & & $11496.0 \pm 670.7$ & (5.7) & $11710.7 \pm 575.1$ & (4.9) \\
\hline 30 & & $9732.6 \pm 473.5$ & $(4.9)$ & $9333.0 \pm 315.9$ & (3.4) \\
\hline 60 & & $9580.1 \pm 431.5$ & (4.5) & $9105.2 \pm 221.4$ & (2.4) \\
\hline 240 & & $9579.2 \pm 397.2$ & $(4.1)$ & $9345.1 \pm 390.6$ & (4.2) \\
\hline
\end{tabular}

Day-old voles had maximum activity in the liver $(\mathrm{CHL}$ about 10 times higher than the CHL of the model reaction). This high level of activity, with some reduction $(18-20 \%)$ persisted up to the 10 th day of the voles' life. The mean level of activity was characteristic of the liver of 20 - and 30-day old voles ( $\mathrm{CHL}$ about 3 times higher). Activity of the liver in 60- and 240-day old voles was low (CHL 1.5-2 times higher). Average level of liver activity was about $17 \%$ and low level only $7-10 \%$ of the high level of liver activity. 
The activity of the kidneys of day-old voles was higher than the activity of the liver in voles of the same age, and was only then on a high level ( $\mathrm{CHL} 10-12$ times higher than $\mathrm{CHL}$ for the model reaction). By the 10th day the activity of kidneys had reached the average level (CHL 5-6 times higher). As from the 20th day of life vole kidney

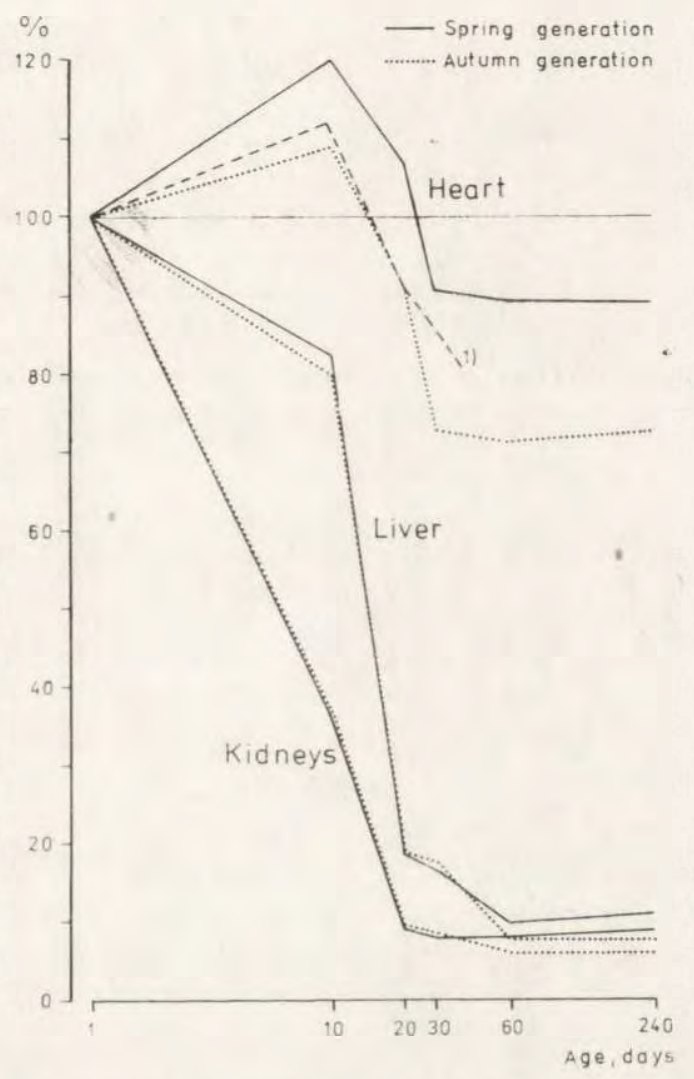

Fig. 3. Variations in oxidation-reduction activity of the organs of laboratory voles of different generations during postnatal development, in relation to the activity of organs in newborn voles $(100 \%), 1) \mathrm{QO}_{2}$ of the heart in spring generation voles after Gębczyński, 1977.

activity remained on a low level ( $C H L 3$ times higher). In spring generation voles the low level of kidney activity did not alter until the 240 th day of life, whereas in autumn generation voles a sort of fourth activity level was evident at the age of 60 and 240 days, about $39 \%$ lower than the activity of the kidneys in 20- and 30-day old voles. Average level of activity of the kidneys was about $36 \%$ and low level 
8-9\% (in autumn generation voles even $6 \%$ ) of the high level of kiduey activity.

The activity in vole hearts was highest in all age groups of these animals in comparison with other organs, and was characterized by least variation during their postnatal development. High activity level in the heart was found in 10-day old voles ( $C H L$ 43-47 times greater than $\mathrm{CHL}$ of the model reaction). In 1- or 20-day voles, however, medium activity was observed in the heart ( $\mathrm{CHL}$ 36-43 times higher). Activity in the heart of voles more than 20 days old was low (CHL $31-32$ times

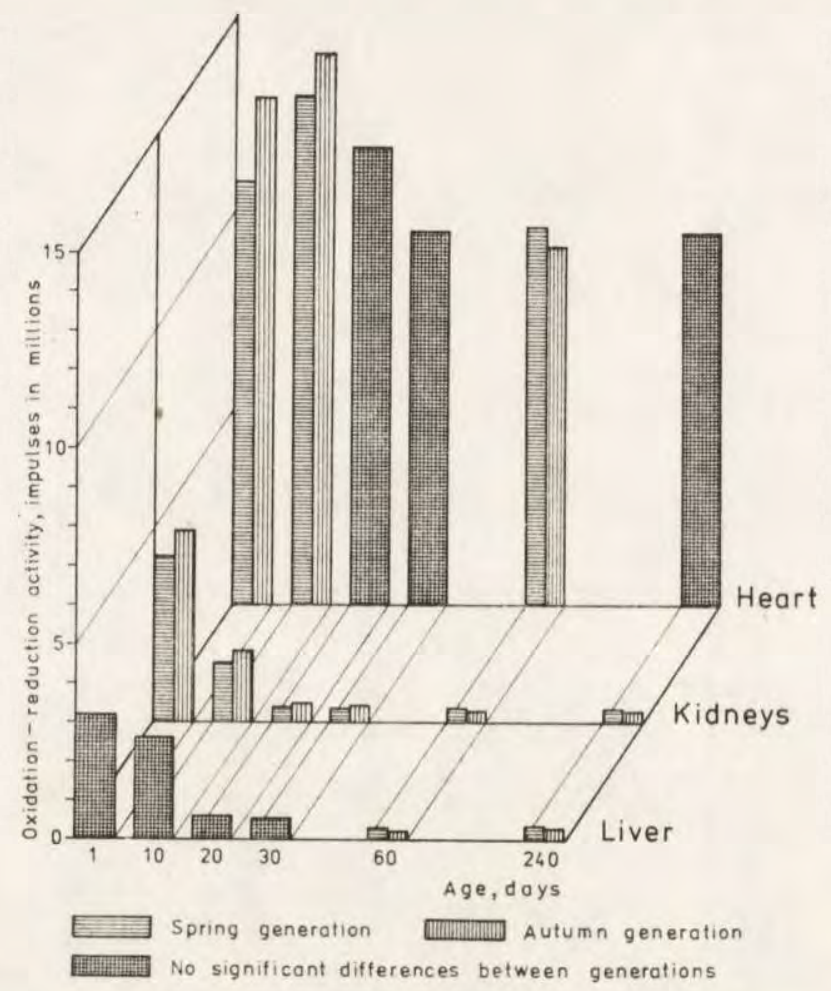

Fig. 4. Oxidation-reduction activity of the organs of laboratory voles of different generations during postnatal development.

greater), and this state persisted up to the 240th day of their life. The average level of activity in vole hearts was $85-88 \%$, and low level $66-74 \%$, of the high level of heart activity.

Establishment of the activity of organs on a given low level characteristic of each organ took place between the 20th and 30th day of the voles' life. The : ctivity of organs was established on a lower level in autumn than in spring generation voles. 
The course taken by variations in the activity of vole organs during postnatal development was similar in voles of both generations, but in different periods of development significantly different activity was found, depending on the season at which the given voles had been born (Fig. 4). One of the organs examined - kidneys differed significantly in respect of activity in voles of the generations compared in all age groups. Activity in the liver was significantly different in voles of the two generations as from the 60th day of life of these animals. As from the first day organs of autumn generation voles were characterized by higher activity than those of spring generation voles. This difference was maintained in different organs up to the 20th or 30th day of the voles' life, after which, as from the 60 th day, voles of the spring generation had greater activity in all organs than voles of the autumn generation.

\subsection{Correlation between Weight and Activity of Organs}

When comparison was made of variations in the absolute weight of organs and their oxidation-reduction activity a statistically significant negative correlation $(P<.001)$ was found between these two indices in voles of both generations for the whole study period of postnatal development (Fig. 5). Coefficients of correlation in the liver and kidneys of voles of the generations compared did not statistically differ significantly, while the coefficient of correlation in the heart of autumn generation voles was significantly higher than in that of spring generation. Taking into account levels of activity of the organs, the whole study period of postnatal development of voles was divided into part periods, in which a different correlation was found for the two indices in organs (Fig. 5). Indices for liver and kidneys of voles from 1 to 20 days old are most strongly correlated, as they are for the heart of voles from 10 to 30 days old in animals of both generations. Correlation of indices decreased with increasing age of the voles in all organs, except that in the liver and kidneys correlation was significant up to the 240 th day of life of the animals $(P<.01)$, but no such correlation was found in the heart of voles as from the 30th day of life.

\section{DISCUSSION}

The INAA method chosen in this study is identical with that used earlier on in studies on wild bank vole (Malzahn, 1981). It makes it possible simultaneously to identify a large number of elements, including those which are rarely included in studies, on account of their extremely small amounts in biological material, and is comparable with 
other methods of identification of certain trace elements (Turkstra et al., 1977). The suitability of the chemiluminescence method in physiological and ecological studies on small mammals has been proved by the example of identifying oxidation-reduction activity in organs of Sorex araneus (Malzahn, 1978). The results obtained earlier in blocking oxidoreducing enzymes in vole tissue homogenates and thermic inactivation of their activity, showed the usefulness of simultaneous examination of trace

Liver
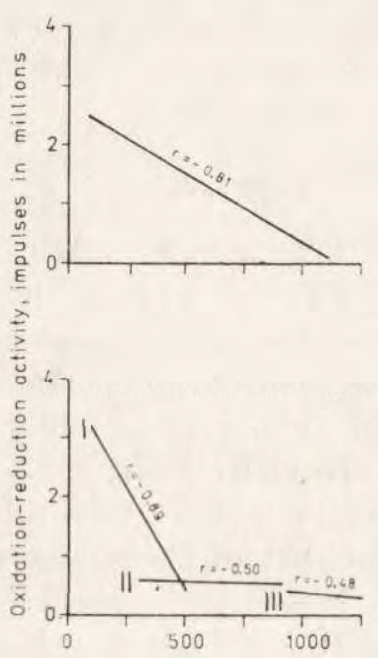

$1-1-20$ days

II $-20-30$

III $-30-240$

-...-.. Spring generation

No significant differences between generations

Kidneys

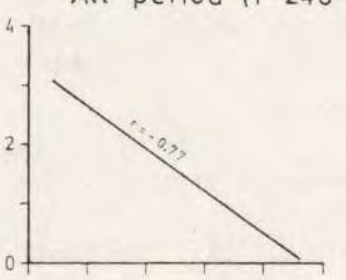

Parts of period

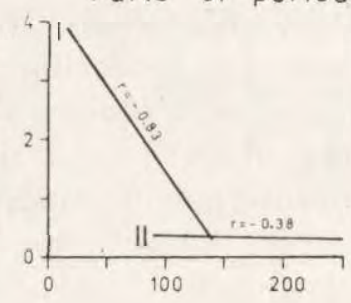

$1-1-20$ days

$11-20-240$
Heart

All period (1-240 days)

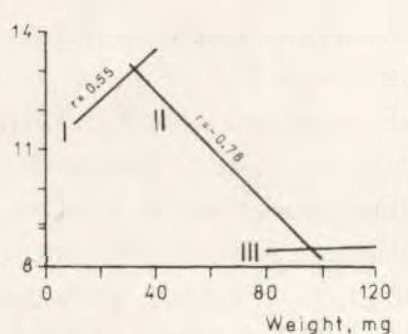

generation
$1-1-10$ days

III- $10-30$
III- $30-240$

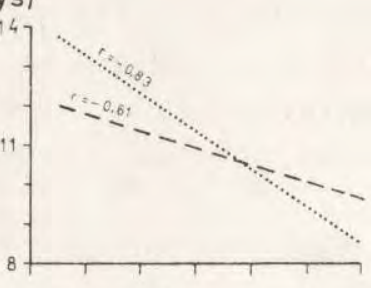$$
40
$$

Fig. 5. Correlation between oxidation-reduction activity and weight of organs in laboratory voles during postnatal development.

element contents and oxidation-reduction activity of vole organs (Malzahn, 1981). Application of the same methods permitted of direct comparison of results obtained for laboratory and wild voles.

A description of variations in the indices examined in the uneven process of postnatal development of small mammals, is given in the paper by Malzahn (1981). The very considerable similarity of such variations in laboratory and wild voles is remarkable and suggests that they occur in all individuals of C. glareolus, irrespective of their origin. 
The following features are characteristic of such variations : 1) maximum concentration of trace elements in organs and maximum oxidationreduction activity of vole organs during the first slower phase of growth (1-10 days of life) and reduction in the two indices during nest development of young voles; 2) maximum differentiation and variation of several indices in vole organs during the phase of accelerated growth (10-30 days of life) ; 3) stabilization of the concentration of the majority of elements and of the lowest level of oxidation-reduction activity in vole organs up to the time at which chemical maturity of the organism is reached, which takes place at different ages in voles of different seasonal generations ; 4) reduction in correlation links between oxidationreduction activity of organs and their weight with increasing age of voles. In all voles considerable similarity was found between variation in the level of activity of their organs during postnatal development and variation in tissue metabolism measured by the respirometric method (Fig. 3). (Gębczyński, 1977), and to variations in the level of total metabolism of small mammals (Gębczyński, 1975 ; Malzahn, 1978).

The features of such variation described above occur in all laboratory voles during postnatal development, although differences were observed between laboratory voles born in spring and autumn. In respect of concentration and contents of trace elements two types of elements were found in the organs of compared generations of voles (Fig. 1). The first type includes $\mathrm{Fe}, \mathrm{Co}$ and $\mathrm{Se}$ and among elements occurring sporadically - Sc, contents of which are higher in organs of autumn generation voles than in those from spring. The second type includes $\mathrm{Zn}, \mathrm{Sb}$ and $\mathrm{Eu}$, the contents of which are greater in the organs of spring generation voles than in those from the autumn. A very large amount of information has been obtained up to the present on the part played by type I elements in the organism, pointing to their direct participation in oxidoreducing processes, whereas the role of certain type II elements is less well known (see Malzahn, 1981).

Differences in the variations of oxidation-reduction activity in the organs of captive voles of different generations during postnatal development are connected with the level of trace element contents. During the period spent in the nest, voles of the autumn generation have from birth onwards greater activity of organs than voles of the spring generation, and thus are physiologically younger. As from the second month of life, however, spring generation voles are physiologically younger than those of the autumn generation. Such differentiation suggests that, as in the case of wild voles, there are differences in the physiological age of animal of the same calendar age in laboratory voles born in spring and autumn. Such differences were found in the case 
of a large number of morphological and physiological indices in voles of extreme seasonal generations living under natural conditions, such as, for instance, attainment of chemical maturity by the organism (Fedyk, 1974b), value of the mitotic index of epithelial tissue (Amstislavskaja, 1970), or tissue metabolism (Gębczyński, 1977). No such differences, on the other hand, were found in laboratory voles (Fedyk, 1974a).

Comparison of voles of extreme seasonal generations of different origin shows that in laboratory voles, as in wild voles, two types of elements were distinguished, differing in respect of their contents in the organs of voles of different generations of comparable age, during postnatal development. When comparing these data it is then possible to distinguish three types of trace elements:

Type I

Higher contents in autumn generation wild

Liver Kidneys Heart

and laboratory voles than in those of the

$\mathrm{Fe}, \mathrm{Co}$,

$\mathrm{Fe}, \mathrm{Co}$,

Fe, Co,

spring generation

$\mathrm{Se}, \mathrm{Ce}$

$\mathrm{Se}, \mathrm{Sc}$

$\mathrm{Se}, \mathrm{Sc}$

Type II

Higher contents in spring generation wild

and laboratory voles than in those of the

autumn generation

$\mathrm{Eu}, \mathrm{Zn}$

$\mathrm{Eu}$

Eu

Type III

Higher contents in autumn generation wild

voles than those from spring, and in spring generation laboratory voles than in those

from autumn

Thus there are two elements from those identified, belonging to type III, the concentration and contents of which in the organs of voles of extreme seasonal generations are directly dependent on the animals' origin (Fig. 6). Very little has yet been discovered as to the role of one of these elements - antimony - in the organism. Its occurrence only has been recorded in many tissues and organs (Kostic et al., 1977) and in mitochondria and nuclein acids obtained from phylogenetically different sources, in which it occurred in identical concentrations (Girardi et al., 1977). This element and its compounds are accumulated in kidneys (Perry et al., 1973) and are considered to be toxic to man. The second of type III elements - zinc - has been thoroughly investigated; essential to animal health and growth and specially connected with somatic growth, osteogenesis and also development and functions of the seminal glands in mammals (Underwood, 1971). This last role of $\mathrm{Zn}$ suggests its connection with the rate of sexual development and fecundity 
of voles born at the beginning and end of the reproduction season (cf. Zejda, 1971). Higher contents of type III elements in organs may point to the greater capacity for adaptation of the organism of voles of this generation, which live in the given habitat under more difficult conditions.

During the study period of the life of both laboratory and wild voles it was impossible to examine the influence of their food on contents of trace elements in their organs, since the voles of different generations examined did not differ in respect of the amount and quality of their food to the same degree as voles living under natural conditions (Gębczyńska, 1976). Wild voles were kept under the same conditions as laboratory voles up to the time they were used for the experiment, but

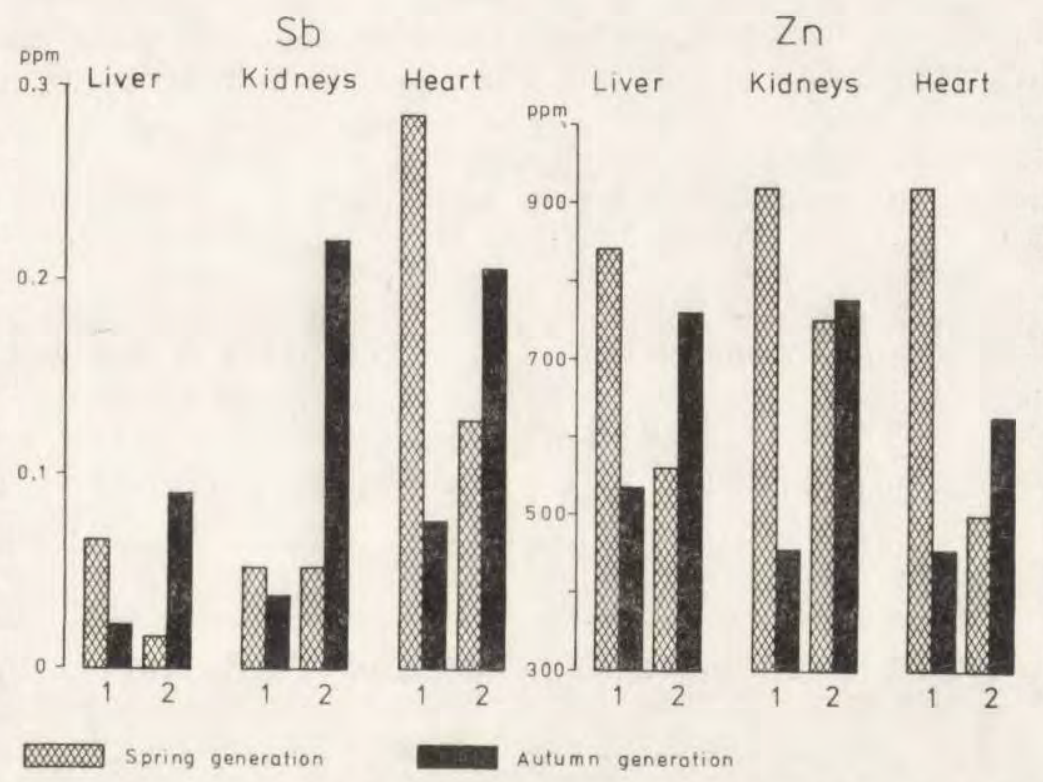

Fig. 6. Mean concentration of two type III elements in organs of (1) laboratory and (2) wild voles of different generations, at the age of $1-60$ days.

the food of all voles was not supplied in doses, and was not a standard diet. Only the generation of the parents of wild voles had fed on natural food, which might have exerted some influence on accumulation of trace elements in the organs of young voles as early as the prenatal period of their development (Malzahn, 1981).

Comparison of wild and laboratory voles during postnatal development in respect of elements contents in the organs of animals of the same generations of comparable age point to the regularities shown in table 5 . In laboratory voles oxidation-reduction activity of organs is also 4-Acta Theriologica 
estabilished on a lower level in voles of the autumn than of the spring generation, i.e. the reverse of the situation in wild voles. Establishment of a low level of activity of organs in laboratory voles takes place at an earlier age than in wild voles. In addition the correlation between weight of the heart and its activity during the whole study period of development was higher in laboratory voles of the autumn than of the spring generation, and in wild voles - in the spring than in the autumn generation.

In wild voles differences between generations at tissue level are clearly correlated with the different rate of growth and development of voles of extreme generations, synchronized with the cyclic changes in habitat conditions. No differences between generations were found in laboratory voles in respect of variations in the proportions of basic components of the body, and the time of their attaining chemical maturity ( $55-60$ day of life) was determined as midway between voles

Table 5

Comparison of laboratory and wild voles during postnatal development in respect of contents of trace elements in the organs of voles of the same generations and of comparable age.

\begin{tabular}{lll}
\hline Organs & $\begin{array}{l}\text { Higher contents in wild voles } \\
\text { than in laboratory voles }\end{array}$ & $\begin{array}{l}\text { Higher contents in laboratory } \\
\text { voles than in wild voles }\end{array}$ \\
\hline $\begin{array}{l}\text { Liver } \\
\text { Kidneys }\end{array}$ & $\begin{array}{l}\text { Autumn generation }: \mathrm{Fe}, \mathrm{Se}, \mathrm{Sb} \\
\text { Autumn generation }: \mathrm{Fe}, \mathrm{Co}, \mathrm{Se},\end{array}$ & $\begin{array}{l}\text { Spring generation : Fe, Se, Sb, } \\
\mathrm{Sb}\end{array}$ \\
Heart & Autumn generation $: \begin{array}{l}\mathrm{Fe}, \mathrm{Co}, \mathrm{Sb}, \\
\mathrm{Eu}, \mathrm{Sc}\end{array}$ & Spring generation: $\mathrm{Fe}, \mathrm{Zn}$ \\
\hline
\end{tabular}

of extreme seasonal generations in the wild (Fedyk, $1974 \mathrm{a}, \mathrm{b}$ ). The laboratory voles examined in this study differed significantly, however, in respect of many indices, depending on the season during which they were born. Contrary differences between laboratory voles born in spring and autumn in comparison with wild voles suggest that such voles during the 8-12th generation of inbreeding adapted themselves to different habitat conditions, which differed diametrically in respect of certain climatic parameters from those in the wild. Air temperature in the breeding rooms in winter was maintained at a constant level of $+18^{\circ}$ to $+20^{\circ} \mathrm{C}$ and under these conditions there was less humidity. In summer, on the other hand, breeding premises are not heated and from time to time the temperature in them may be lower than temperature level in winter, while air is more humid than in winter. Changes of this kind in habitat condition have earlier been found to affect the heat conduction of the fur of several species of small mammals (Gęb- 
czyński \& Olszewski, 1963). In animals obtained from wild conditions the fur is less insulating in summer than in winter, whereas animals kept under laboratory breeding conditions have similar insulating value of both winter and summer fur, and even winter fur has a higher heat conduction value than summer fur. The authors explain this phenomenon by disturbances in the course of moulting caused by the stability of thermal conditions in a laboratory habitat.

As can be seen from the studies compared, wild voles are characterized by a more distinct difference between morphological indices of their organs, the contents in them of trace elements and the oxidationreduction activity of organs of voles of different generations, than is the case with voles laboratory-bred for many generations. Average increases in body weight are greater in wild than in laboratory voles during postnatal development, while the relative weights of organs

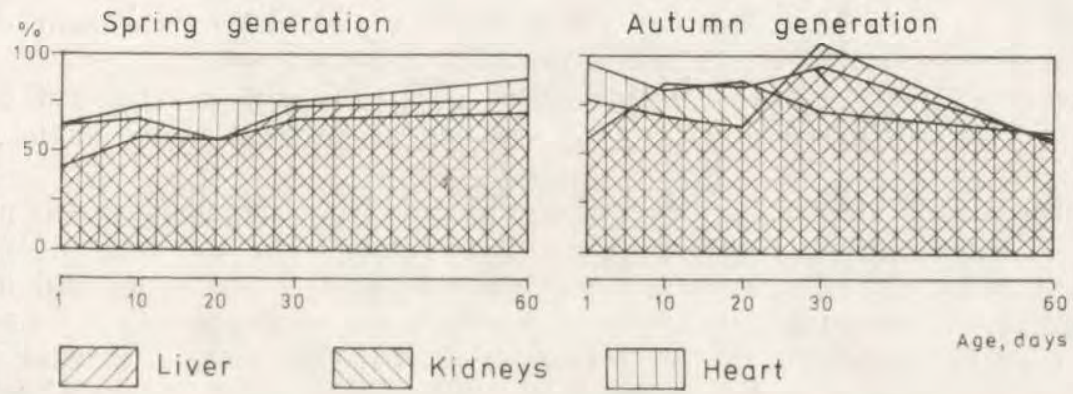

Fig. 7. Comparison of oxidation-reduction activity of the organs of laboratory and wild $(100 \%)$ voles of different generations during postnatal development.

during the same periods of life are greater in laboratory voles in comparison with wild animals. Significant differences between voles of different origin are contained in the higher average concentrations and contents of the majority of elements in the organs of wild voles from 1 - to 60 days old than in the organs of laboratory voles. The higher oxidation-reduction activity of the organs of wild voles as compared with laboratory voles, over the whole study period of postnatal development (Fig. 7), justifies the assumption that voles obtained from parents caught under wild conditions are metabolically active at comparable age than laboratory-bred voles.

Despite these differences the diagrams of the course taken by variations in morphological and physiological indices obtained for vole organs of differing origin are similar during postnatal development and may be treated as characteristic of all the study voles originating from the Białowieża National Park. 
The results obtained during studies on laboratory voles provide confirmation of conclusions drawn from the results of studies on wild voles. Together with a change in habitat conditions basic metabolism may decrease and development of age changes may be inhibited. The wide range in rate of the ageing process in different individuals of the bank vole suggests there it may be possible to steer this process.

\section{REFERENCES}

1. Amstislavskaja T.S., 1970: Dinamika mitotičeskoj aktivnosti v pokrovnyh tkaniah polevki Clethrionomys glareolus raznyh sezonnyh generacji. Ekologija, $4: 68-74$.

2. Buchalczyk A., 1970: Reproduction, mortality and longevity of the bank vole under laboratory conditions. Acta theriol., 15: 153-176.

3. Davies I.J.T., 1977: Medical significance of the essential biological metals. J. Radioanal. Chem., 37 : 39-64.

4. Fedyk A., 1974 a: Gross body composition in postnatal development of the bank vole. I. Growth in captivity. Acta theriol., 19: 381-401.

5. Fedyk A., 1974 b: Gross body composition in postnatal development of the bank vole. II. Differentiation of seasonal generations. Acta theriol., 19: 403-427.

6. Gębczyńska Z., 1976: Food habits of the bank vole and phenological phases of plants in an oak hornbeam forest. Acta theriol., 21: 223-236.

7. Gębczyński M., 1975: Heat economy and the energy cost of growth in the bank vole during the first month of postnatal life. Acta theriol., 20:379-434.

8. Gębczyński M., 1977: Postnatal changes in tissue respiration of bank voles born in different season. Bull. Acad. Polon. Sci., Cl. II, 25: 405-409.

9. Gębczyński M. \& Olszewski J., 1963: Katathermometric measurements of insulating properties of the fur in small mammals. Acta theriol., 7: 399-402.

10. Girardi F., Marafante E., Pietra R., Sabbioni E. \& Marchesini A., 1977: Application of neutron activation analysis to metallobiochemistry. J. Radioanal. Chem., 37: 427-440.

11. Grodzińska K., 1980: Zanieczyszczenie polskich parków narodowych metalami ciężkimi. Ochrona Przyrody, 43: 9-27.

12. Jakutowicz K., 1973: Zastosowanie analizy aktywacyjnej w badaniach medycznych na przykładzie niektórych pasożytów. Post. Fiz. Med., 8, 1-2: 109-117 .

13. Kabata-Pendias A. \& Pendias H., 1979: Pierwiastki śladowe w środowisku biologicznym. Wyd. Geologiczne: $1-300$, Warszawa.

14. Kostić K., Drašković R. J., Ratković M., Kostić D. \& Drašković R.S., 1977: Determination of some trace elements in different organs of normal rats. J. Radioanal. Chem., 37: 405-413.

15. Malzahn E., 1978: The oxidation-reduction activity of organs in Sorex araneus Linnaeus, 1758. Comp. Biochem. Physiol., 62 A : 909-913.

16. Malzahn E., 1981: Trace elements and their significance in the postnatal development of seasonal generations of the bank vole. Acta theriol., 26: $231-256$. 
17. Perry H. M., Perry E.F., Purifoy J.E. \& Erlanger J. N., 1973 : A comparison of intra- and interhepatic variability of trace metal concentrations in normal men. Trace Subst. Env. Health, $7: 281-288$.

18. Petrusewicz K., Andrzejewski R., Bujalska G. \& Gliwicz J., 1969/70: The role of spring, summer and autumn generations in the productivity of a freeliving population of Clethrionomys glareolus. [In: "Energy flow through small mammal populations." Eds K. Petrusewicz \& L. Ryszkowski]. Państw. Wyd. Nauk. : 235-245, Warszawa.

19. Turkstra J., Harthoorn A. M., Benkes P.J. L. \& Brits R. J. N., 1977: The influence of seasonal changes in the concentration of trace elements by instrumental neutron activation analysis. J. Radioanal. Chem., 37: 473-481.

20. Underwood E.J., 1971: Trace elements in human and animal nutrition. Academic Press : $1-543$, New York.

21. Zejda J., 1971: Differential growth of three cohorts of the bank vole, Clethrionomys glareolus Schreb, 1780. Zool. Listy, 20:229-245.

Accepted, December 10, 1982.

Elżbieta MALZAHN

\section{POSTNATALNE ZMIANY W PIERWIASTKACH SLADOWYCH \\ U LABORATORYJNEJ NORNICY RUDEJ}

\section{Streszczenie}

Zmierzono koncentracje 10 pierwiastków śladowych (Fe, Zn, Co, Se, Sb, Eu, $\mathrm{Cr}, \mathrm{Hg}, \mathrm{Sc}$ i $\mathrm{Ce}$ ) w aktywnych metabolicznie organach (wątroba, nerki i serce) nornicy rudej, Clethrionomys glareolus (Schreber, 1780) w ciągu pierwszych dwóch miesięcy jej życia (Tabela 2) metodą instrumentalnej neutronowej analizy aktywacyjnej (INAA). Do badań użyto 394 nornice $w$ sześciu grupach wiekowych $(1,10,20,30,60$ i $240 \mathrm{dni})$ ze skrajnych generacji sezonowych: wiosennej i jesiennej, pochodzących z 8-12 pokolenia hodowanego osobnie w Zakładzie Badania Ssaków PAN w Białowieży (Tabela 1). Wyróżniono dwa typy pierwiastków, różniące się zawartością $w$ organach nornic porównywanych generacji: $\mathrm{Fe}, \mathrm{Co}$, Se i Sc (typ I) zawieraly więcej organy nornic generacji jesiennej niż wiosennej, a $\mathrm{Zn}, \mathrm{Sb}$ i Eu (typ II) zawieraly więcej organy nornic generacji wiosennej niż jesiennej (Tabela 3, Ryc. 1). Największe średnie zawartości większości pierwiastków występowały w wątrobie, a najmniejsze w sercu nornic (Ryc. 2).

Zmienność koncentracji pierwiastków w organach nornic w trakcie rozwoju postnatalnego jest podobna do zmienności aktywności oksydoredukcyjnej organów mierzonej metodą chemiluminescencji (Tabela 4, Ryc. 4). Maksymalną aktywnością, podobnie jak maksymalną koncentracją pierwiastków, charakteryzują się nornice obu generacji w wieku 1 lub 10 dni, po czym następuje zmniejszanie się obu wskaźników w okresie rozwoju gniazdowego (Ryc. 3). W późniejszym wieku 
nornic aktywność ich organów ulega dalszemu obniżeniu aż do ustalenia się niskiego jej poziomu, charakterystycznego dla osobników dorosłych, który organy nornic osiągają około trzydziestego dnia życia zwierząt. Nornice generacji jesiennej mają wyższy poziom aktywności organów po urodzeniu, ale od 60-go dnia życia wyższą aktywność mają organy nornic generacji wiosennej niż jesiennej. Stwierdzono istotną ujemną korelację między aktywnością organów i ich ciężarem u nornic obu generacji w calym badanym okresie rozwoju (1-240 dni życia), zmniejszająca się wraz z wiekiem zwierząt (Ryc. 5).

Zmienność badanych wskaźników u nornic hodowlanych porównano z uzyskanymi wcześniej wartościami tych samych wskaźników u nornic terenowych. Wyróżniono trzeci typ pierwiastków ( $\mathrm{Sb}, \mathrm{Zn})$, których zawartość jest większa w organach nornic hodowlanych generacji wiosennej niż jesiennej, natomiast $u$ nornic terenowych - generacji jesiennej niż wiosennej (Ryc. 6). Stwierdzono przeciwstawne różnice między zawartością pierwiastków śladowych w organach nornic terenowych skrajnych generacji sezonowych w porównaniu z nornicami hodowianymi (Tabela 5). Nornice hodowlane charaḱteryzują się niższą aktywnością oksydoredukcyjną organów niż nornice terenowe w ciągu całego badanego okresu rozwoju postnatalnego (Ryc. 7). Zmienność uzyskanych wskaźników analizowano w aspekcie mechanizmów starzenia się osobników różnego pochodzenia z różnych generacji sezonowych nornicy rudej. 